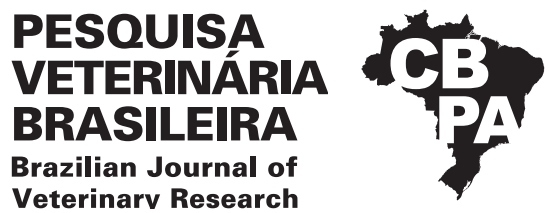

Pesq. Vet. Bras. 40(12):977-984, December 2020 DOI: 10.1590/1678-5150-PVB-6731

Original Article

Veterinarv Research

ISSN 0100-736X (Print)

ISSN 1678-5150 (Online)

\title{
Indirect ELISA (iELISA) standardization for the diagnosis of bovine enzootic leukosis ${ }^{1}$
}

\author{
Cláudia F. Resende ${ }^{2}$, Grazielle C. F. Galinari², Raphael M. Victor ${ }^{3}$, Telissa C. Kassar², \\ Thiago L.M. Arcebispo ${ }^{4}$, Emília Delarmelina², Romulo C. Leite ${ }^{2}$ \\ and Jenner K.P. Reis ${ }^{2 *}$
}

\begin{abstract}
Resende C.F., Galinari G.C.F., Victor R.M., Kassar T.C., Arcebispo T.L.M., Delarmelina E., Leite R.C. \& Reis J.K.P. 2020. Indirect ELISA (iELISA) standardization for the diagnosis of bovine enzootic leucosis. Pesquisa Veterinária Brasileira 40(12):977-984. Laboratório de Retroviroses, Departamento de Medicina Veterinária Preventiva, Escola de Veterinária, Universidade Federal Minas Gerais, Campus Pampulha, Av. Antonio Carlos 6627, Belo Horizonte, MG 31270-901, Brazil. E-mail: jenner@ufmg.br

Enzootic bovine leukosis (EBL) is an infectious disease caused by bovine leukemia virus (BLV) that affects cattle worldwide. Agar gel immunodiffusion (AGID) was the reference test for EBL diagnosis for many years, but enzyme-linked immunosorbent assay (ELISA) showed higher sensitivity, was faster to perform, and resulted in an objective reading. However, the importation of ELISA kits is lengthy and expensive, and currently, no AGID kits are available in Brazil. The aim of this work was to standardize an indirect ELISA (iELISA) for EBL diagnosis using BLV antigens produced in Tadarida brasiliensis lung (Tb1Lu) cells, which are Bovine viral diarrhea virus (BVDV) free, unlike fetal lamb kidney (FLK) cells, currently used for this purpose. Following standardization, iELISA results were compared with those obtained by AGID and the commercial Chekit Leucose-Serum ELISA. Compared to AGID, iELISA had $94,44 \%$ sensitivity, $75.68 \%$ specificity, $79.10 \%$ positive predictive value (PPV) and $93.30 \%$ negative predictive value (NPV), with $84 \%$ concordance and a Kappa index of 0.699. Compared to the Chekit Leucose-Serum ELISA, iELISA showed $92.60 \%$ sensitivity, 87.09\% specificity, 90.27\% PPV and 90,00\% NPV, with $90.27 \%$ concordance and a Kappa index of 0.801 . Taking into account the high agreement with the traditional tests and the absence of non-specific reactions with BVDV, the developed assay could be used as diagnostic method to control EBL in Brazil.
\end{abstract}

INDEX TERMS: iELISA, bovine, enzyme-linked immunosorbent assay, Enzootic bovine leukosis, diagnosis, control, cattle.

\begin{abstract}
RESUMO.- [Padronização de um ELISA indireto (iELISA) para diagnóstico da leucose enzoótica bovina.] A leucose enzoótica bovina (LEB) é uma doença infecciosa natural dos bovinos com distribuição mundial causada pelo "bovine leukemia virus" (BLV). A imunodifusão em gel de ágar (IDGA) foi considerada por muitos anos o teste de eleição, porém ensaios imunoenzimáticos (ELISA) apresentam sensibilidade
\end{abstract}

\footnotetext{
${ }^{1}$ Received on September 11, 2020.

Accepted for publication on September 28, 2020.

${ }^{2}$ Graduate Program in Animal Science, Laboratório de Retroviroses, Departamento de Medicina Veterinária Preventiva, Escola de Veterinária, Universidade Federal Minas Gerais (UFMG), Campus Pampulha, Av. Antônio Carlos 6627, Belo Horizonte, MG 31270-901, Brazil. *Corresponding author: jenner@ufmg.br

${ }^{3}$ Ministério da Agricultura Pecuária e Abastecimento (MAPA), Manaus, AM, Brazil.

${ }^{4}$ Ministério da Agricultura Pecuária e Abastecimento (MAPA), Brasília, DF, Brazil.
}

mais elevada e leitura mais rápida e objetiva. No entanto, a importação de kits de ELISA é um processo dispendioso e demorado, e atualmente não há kits de IDGA comercialmente disponíveis no Brasil. Desta forma, o objetivo deste trabalho foi padronizar um ELISA indireto (iELISA) para diagnóstico da LEB utilizando antígenos produzidos a partir do cultivo do BLV em linhagem celular Tadarida brasiliensis "lung" (Tb1Lu) livre de "bovine viral diarrhea virus" (BVDV), diferentemente do que acontece com as linhagens "fetal lamb kidney" (FLK) atualmente utilizadas na produção desses antígenos para uso em ensaios sorológicos. Após a padronização do iELISA, os resultados foram comparados com aqueles obtidos por IDGA e pelo ELISA comercial "Chekit Leucose-Serum". Comparado ao IDGA, o iELISA apresentou $94,44 \%$ de sensibilidade, $75,68 \%$ de especificidade, valor preditivo positivo (VPP) 
de 79,1\% e valor preditivo negativo (VPN) de 93,3\%, com concordância entre os testes de 84\% e o índice Kappa 0,699. Quando comparado ao ELISA “Chekit Leucose-Serum", o iELISA apresentou sensibilidade de 92,6\%, especificidade de 87,09\%, VPP de 90,27\% e VPN de 90\%, com concordância de 90,27\% e o índice Kappa 0,801. Portanto, devido à alta concordância com os testes tradicionais e ausência da ocorrência de reações inespecíficas com BVDV, o ensaio desenvolvido pode ser utilizado como ferramenta diagnóstica para o controle da LEB no Brasil.

TERMOS DE INDEXAÇÃO: iELISA, bovinos, ensaio de imunoadsorção enzimática, leucose enzoótica bovina, diagnóstico, controle.

\section{INTRODUCTION}

Enzootic bovine leukosis (EBL) is an infectious and contagious disease of cattle caused by bovine leukemia virus (BLV), a B-cell lymphotropic virus of the genus Deltaretrovirus, family Retroviridae. The disease is characterized by a long incubation period, with 1-5\% of infected animals developing lymphosarcoma, an often-fatal clinical form of the disease, while approximately 30\% develop persistent lymphocytosis. However, the inapparent form is the most frequent, with the asymptomatic animal being an important source of BLV transmission (Camargos et al. 2004, De Oliveira et al. 2016).

The disease is debilitating in animals that develop lymphosarcoma, leading to death within weeks or months after the onset of clinical manifestations. BLV infection compromises the immune response of the host, predisposing the host to secondary infections, leading to earlier animal disposal and increasing costs of production due to carcass condemnation, veterinary services, medication and treatment of sick animals (Trainin \& Brenner 2005, OIE 2012, Leite et al. 2013). The dairy industry is directly affected, both by the lower survival of EBL positive cows and by decreases in milk production, especially among animals with persistent lymphocytosis (Nekouei et al. 2016). Rajão et al. (2014) estimates that in Brazil, BLV infection results in losses higher than 100 dollars per cow per lactation, which represents a significant economic loss, especially for small producers. There is also economic loss related to restrictions in exportation. Some countries, especially those in the European Union, have a ban on BLV-infected animals and biological products of animal origin, such as semen and embryos (Larsen et al. 2013). In addition to its economic relevance, in recent years BLV has been studied in relation to human health. There is some evidence that suggest BLV infection in women that is likely associated with the development of breast cancer (Buehring et al. 2014, 2017, Khalilian et al. 2019).

The prevalence of BLV infection in dairy herds may reach $60-90 \%$ in many countries. Serological surveys revealed that EBL is endemic, with high prevalence rates in North America, South America, Africa, Asia and Australia. In Brazil, it has been detected in several states, with serological prevalence varying from $8.9 \%$ to $53.2 \%$ (Romero \& Rowe 1981, Molnár et al. 1999, Camargos et al. 2002, 2004, Carneiro et al. 2003, Megid et al. 2003, Poletto et al. 2004). Identification and isolation of seropositive animals is necessary to control virus dissemination, and serological tests should be performed periodically for this purpose. The gp51 glycoprotein of the viral envelope is highly immunogenic and therefore widely used in serological diagnostic tests. The protein p24 is also used since it is the main viral capsid protein and induces a strong immune response (Troiano et al. 2013, De Oliveira et al. 2016).

For many years the agar gel immunodiffusion (AGID) test, used for individual serum or plasma samples, was the test of choice for the diagnosis of EBL, especially for its practicality and low cost. However, despite its easy applicability, it failed to detect low titers of antibodies, especially in recent infections or in animals with a reduced antibody response, which implied the occurrence of false-negative results. In recent years, enzymelinked immunosorbent assay (ELISA) tests have been developed for pooled use or in individual serum and milk samples. When compared to the AGID, these tests have higher sensitivity and an objective reading, allowing the testing of a large number of samples simultaneously, with results in a few hours (OIE 2012, Troiano et al. 2013, Bai et al. 2019).

The AGID is still the most used test for the diagnosis of EBL in Brazil, but there is no national commercial test available and international tests use antigen produced in fetal lamb kidney (FLK) cells persistently infected with BLV. However, it is known that this cell line is susceptible to Bovine viral diarrhea virus (BVDV) contamination, which may negatively influence the specificity of the test due to potential non-specific reactions (Camargos et al. 2007). In 1995, BLV-free bovine herds were vaccinated against BVDV and subsequently an increasing number of positive results for this disease were detected by ELISA, but analyzes of these reactions by other serological tests and PCR provided negative results for EBL. Thus, false positive results have been associated with cross-reactivity against anti-BVDV antibodies induced by vaccination (Beier \& Conraths 1996 apud Beier et al. 2004).

A BVDV-free and BLV-permissive cell line would be an alternative for antigen production for diagnostic use, as it eliminates the likely occurrence of non-specific reactions. Previous studies have shown that Tadarida brasiliensis lung (TB1Lu) bat cells are highly permissive to BLV, with a progressively increased production of viral particles, reaching high levels of replication after a short culture period, (Graves \& Ferrer 1976, Patrascu 1988, Suzuki et al. 2018). In addition, these cells are also resistant to BVDV infection according to the American Type Culture Collection manual (ATCC ${ }^{\circledR}$ CCL-88 ${ }^{\mathrm{TM}}$ ), presenting a suitable source for the research and production of virus-related antigens. Thus, the aim of the present study was to develop an indirect ELISA that used antigen produced in a Tb1Lu cell line infected with a Brazilian BLV isolate to be used as a diagnostic tool, in addition to AGID, for the control of EBL.

\section{MATERIALS AND METHODS}

Bovine serum. Seventy-three serum samples of same-farmed calves, kindly provided by Professor Elias Jorge Facury Filho from the "Universidade Federal de Minas Gerais" (UFMG), were collected before $(n=32)$ and after $(n=41)$ colostrum suckling. Considering the high prevalence of EBL in Brazilian cattle and the difficulty of obtaining samples from a BLV-free herd, we adopted the strategy of obtaining serum from non-colostrum-fed (NCF) calves to be used as a negative control. All procedures for handling and collecting animal samples were approved by the Ethics Committee on the Use of Animals of the UFMG under protocol number 151/2015.

AGID. Serum samples were tested using the AGID test, as a reference for this standardization, and for comparison purposes. A commercial AGID kit for enzootic bovine leucosis diagnosis (TECPAR, Brazil) was used for anti-gp51 antibody detection, using 
crude antigen produced in a FLK cell line persistently infected with bovine leukemia virus (BLV), following the manufacturer's recommendations. The reading was performed after 72 hours of incubation at $25^{\circ} \mathrm{C}$ (room temperature-RT).

Chekit Leucose-Serum ELISA (IDEXX Laboratories, USA). All samples were tested using the commercial ELISA (Chekit Leucose-Serum), an indirect ELISA using microplates coated with inactivated BLV crude antigen. Tests were performed following the manufacturer's recommendations.

Virus. The Tb1Lu cell line $\left(\right.$ ATCC $^{\circledR}$ CCL-88 ${ }^{\mathrm{TM}}$ - American Type Culture Collection, USA), pre-infected with a Brazilian BLV field isolate (GenBank accession number: KU255419) was used. To guarantee the absence of BVDV, the cells, fetal bovine serum (FBS), trypsin and Minimum Essential Medium Eagle (MEM) (Sigma, USA) were previously tested by polymerase chain reaction (PCR) at the "Laboratório Federal de Defesa Agropecuária" (LFDA), and were all negative for this virus. Cultivation was carried out in MEM containing $1 \%$ penicillin/streptomycin, $0.5 \%$ fungizon, and $25 \mathrm{mM}$ HEPES, supplemented with 5\% FBS. The cells were incubated in a $5 \% \mathrm{CO}_{2}$ atmosphere at $37^{\circ} \mathrm{C}$ until reaching approximately $80 \%$ confluence, when the cells were subcultured. At the time of each passage, the medium supernatant was collected and stored at $-20^{\circ} \mathrm{C}$ for virus purification.

BLV antigen (BLV-Ag) production. Supernatants and monolayers of the cell cultures were subjected to three cycles of freezing and thawing for cell disruption and release of viral particles and proteins. The cell suspension was centrifuged at $925 \times g$ for $30 \mathrm{~min}$ at $4^{\circ} \mathrm{C}$, the supernatant was collected and $0.318 \mathrm{~g}$ of ammonium sulfate was added to each $1 \mathrm{~mL}$ of supernatant, which was stirred for 1 hour at $4^{\circ} \mathrm{C}$. Then, centrifugation was performed again at $4000 \times \mathrm{g}$ for $30 \mathrm{~min}$ at $4^{\circ} \mathrm{C}$. The precipitate was dissolved in a small volume of phosphate buffered saline (PBS) and transferred to a dialysis membrane. The antigen preparation was dialyzed against $1 \times$ PBS, at a volume of $100 \times$ the membrane-contained volume, at $4^{\circ} \mathrm{C}$, stirring. The first dialysis lasted for 12 to 14 hours and the second dialysis, for approximately four hours. After this procedure, the dialysis membrane was covered with polyethylene glycol (PEG 6000) at $4^{\circ} \mathrm{C}$ to concentrate the antigen. The concentrated antigen solution was then transferred to a microtube and 10\% Triton X-100 and $1 \%$ protease inhibitor (Sigma, USA) was added. The total protein concentration of the final antigen preparation was estimated using the Total Protein Monoreagent Kit (Bioclin, Brazil), following the manufacturer's recommendations. The final antigenic product was stored at $-20^{\circ} \mathrm{C}$ until use.

Polyacrylamide gel electrophoresis. For disaggregation and analysis of protein content, the antigen produced was subjected to polyacrylamide gel electrophoresis using a $10 \%$ Amersham $^{\mathrm{TM}} \mathrm{ECL}^{\mathrm{TM}}$ Gel (GE Healtcare Life Sciences, USA), according to the manufacturer's recommendations. After electrophoresis, the Amersham ${ }^{\mathrm{TM}} \mathrm{ECL}^{\mathrm{TM}} \mathrm{Gel}$ was stained with Coomassie Blue Brilliant R-350.

Indirect ELISA (iELISA) standardization. Polystyrene 96-well plates (Maxsorb, Nunc, Hampton, NH, USA) were coated with $0.5 \mathrm{ng}$ or 1.0ng per well BLV-Ag produced in Tb1Lu cells, diluted in $0.05 \mathrm{M}$ carbonate buffer $\mathrm{pH} 9.6$ (containing $0.015 \mathrm{M}$ sodium carbonate and $0.035 \mathrm{M}$ sodium bicarbonate); $100 \mu \mathrm{L}$ diluted BLV-Ag was added per well and incubated overnight at $4^{\circ} \mathrm{C}$. The next day, the plate was washed twice with $200 \mu \mathrm{L}$ per well $1 \times$ PBS with $0.05 \%$ Tween 20 (PBST), followed by incubation for 1 hour at RT with $100 \mu \mathrm{L}$ PBST containing $5 \%$ skim milk to block non-specific binding sites, and three washes with $200 \mu \mathrm{L}$ PBST. Then, $100 \mu \mathrm{L}$ serum samples, two-fold serially diluted in PBST with $1 \%$ skim milk, were added in duplicate wells and the plate was kept at RT for 1 hour, followed by three washes with PBST. Two positive controls (a pool of positive samples and one colostrum-fed calf serum) and two negative controls (BFS and one NCF calf serum) were added to each plate. After the washes, $100 \mu \mathrm{L}$ anti-bovine IgG peroxidase conjugated (Sigma), tested at dilutions of 1:5000 and 1:7500, in PBST with 1\% skim milk, was added per well and the plate was incubated at RT for 1 hour. Three further washes with $200 \mu \mathrm{L}$ PBST were performed, followed by incubation with $100 \mu \mathrm{L}$ per well $0.5 \mathrm{mg} / \mathrm{mL} \mathrm{o-phenylenediamine}$ (OPD) substrate, diluted in acid buffer $\mathrm{pH} 5.0$ (citric acid $0.1 \mathrm{M}$, sodium phosphate $0.2 \mathrm{M}$ and $0.003 \%$ of 30 volumes hydrogen peroxide) at RT for $20 \mathrm{~min}$, in the dark. The reaction was stopped with $40 \mu \mathrm{L}$ of $1 \mathrm{M}$ sulfuric acid in each well. Plates were read in an ELISA reader (Thermo Plate TP-Reader) at an absorbance of $492 \mathrm{~nm}$. The cut-off point was calculated using the MedCalc program, version 13.0.0.0 (MedCalc Software, Mariakerke, Belgium) based on the receiver operating characteristic (ROC) curve analyses.

Statistical analysis. A contingency table $(2 \times 2)$ was used to compare tests. The positive predictive value (PPV), negative predictive value (NPV), sensitivity, and specificity values for AGID and the Chekit Leucose-serum ELISA, the concordance between tests and the Kappa index were evaluated.

\section{RESULTS}

\section{Antigen production (BLV-Ag)}

The BLV-Ag produced in this study had a total protein concentration estimated at $6.19 \mu \mathrm{g} / \mu \mathrm{L}$. To verify the presence of viral proteins, BLV-Ag was separated by sodium dodecyl sulfate-polyacrylamide gel electrophoresis (SDS-PAGE). A unique band corresponding to $51 \mathrm{kDa}$ was detected in the gel, indicating the presence of the viral envelope glycoprotein gp51 (Fig.1).

\section{iELISA and comparative analysis with commercial tests}

The standardized iELISA was performed under the following conditions: $1.0 \mu \mathrm{g}$ BLV-Ag per well, a serum dilution of 1:25 and conjugate dilution of 1:5000. Under these conditions, a higher discrimination between positive and negative sera was obtained, based on the AGID results, used as reference test. Figure 2 shows the relationship between the optical density (OD), frequency, and the distribution of 36 (49.31\%) positive and 37 (50.69\%) negative sera in AGID. Twenty-seven negative sera by AGID and two positive sera had an OD lower than 0.100; when the OD values were between 0.100 and 0.150 , the number of positives in AGID increased to 12, while the amount of negatives dropped to six; readings above 0.200 were all positive.

The ROC curve analysis using the field samples indicated a cutoff point of an OD equal to 0.104 (Fig.3A). Thus, the field samples were considered positive when they presented an OD above 0.104 . The diagnostic capacity of the test was measured by assessing its sensitivity and specificity for AGID, which were $94.44 \%$ and $75.68 \%$, respectively, with a $95 \%$ confidence level. The PPV was $79.1 \%$ and the NPV was $93.3 \%$. The agreement between tests was $84 \%$ and the Fleiss' Kappa index was 0.699, classified as substantial (0.61-0.80) (Lage et al. 2016) (Table 1).

Of the 73 serum samples tested, 43 (58.9\%) were positive in the iELISA, of which, nine (12.32\%) were negative by AGID. Thirty samples (41.09\%) were considered negative by iELISA, two of which (2.73\%) were positive by AGID (Fig.3B). 


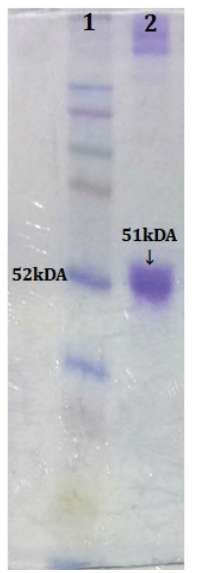

Fig.1. Sodium dodecyl sulfate-polyacrylamide gel electrophoresis of the bovine leukemia virus antigen (BLV-Ag) stained using Coomassie Blue Brilliant R350 Tadarida brasiliensis lung (Tb1Lu) cells. Molecular weight marker (column 1), BLV-Ag preparation (column 2).

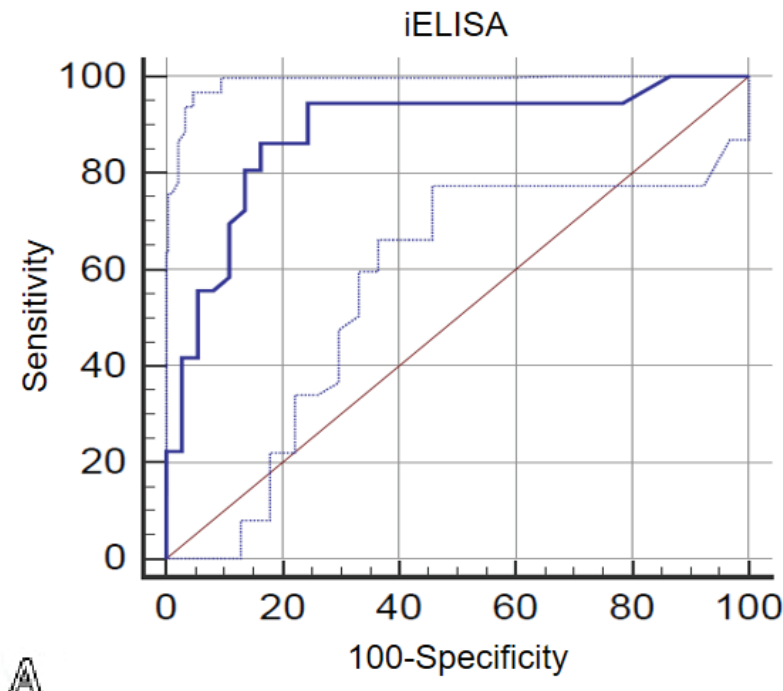

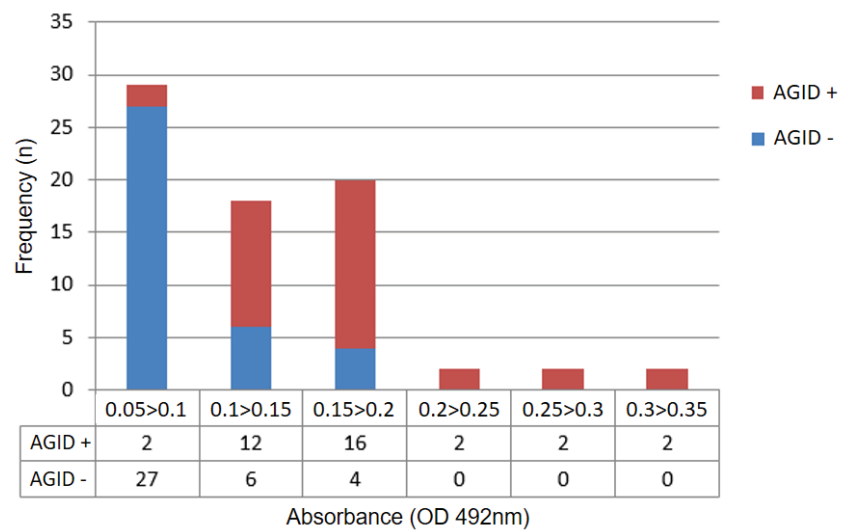

Fig.2. Sera distribution by optical density (OD) in the indirect enzyme-linked immunosorbent assay (iELISA) compared to agar gel immunodiffusion (AGID).

\section{iELISA}

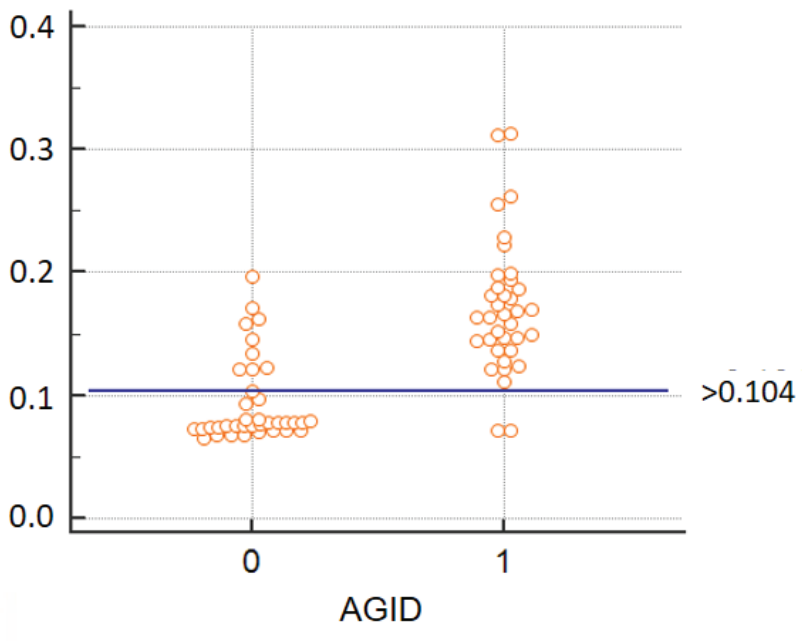

Fig.3. Determination of the cut-off point of the indirect enzyme-linked immunosorbent assay (iELISA) with reference to agar gel immunodiffusion (AGID). (A) Receiver operating characteristic (ROC) curve analysis based on results obtained from tested field samples. The area under the curve is calculated as 0.883 , with a $95 \%$ confidence interval. (B) Comparison of results from the sera of 73 calves tested by iELISA and AGID. Negative samples by AGID (0), positive samples by AGID (1).

Figure 4 shows the comparison of the results of the 72 samples tested by iELISA and the Chekit ELISA. For analysis of the sensitivity, specificity, concordance and kappa values, the sample with an undetermined result by the Chekit ELISA was excluded. Thus, iELISA showed a sensitivity of $92.6 \%$ and a specificity of $87.09 \%$ compared to the Chekit ELISA, with a PPV of $90.27 \%$, and a NPV of $90 \%$. The concordance between the tests was $90.27 \%$ and the Kappa value was 0.801 (Table 2).

\section{Overall analysis of the results}

As expected, most colostrum-fed (CF) calf serum samples were positive and the NCF calves were negative in all three assays. However, a small number of $\mathrm{CF}$ calves were diagnosed as negative and NCF calves as positive (Table 3). There was a disagreement between 11 (15.06\%) serum samples; one sample positive by iELISA had a negative result by AGID and was undetermined using the Chekit ELISA. Five samples, two of non-colostrum fed animals, were positive by iELISA and negative in the other two tests. Unexpectedly, one NCF serum was positive by AGID and negative by ELISA.

\section{DISCUSSION}

Currently AGID is the only test used for EBL diagnosis in Brazil and in many other countries. Although there is no national kit available, this technique continues to be the most practical and economical, and it has been adopted by most governments as the official test used in importation processes. However, due to the high prevalence of bovine leukemia virus (BLV) in Brazilian herds, it is not feasible to use it in epidemiological studies and control programs, since a large number of samples have to be tested (Camargos et al. 2007, Troiano et al. 2013). For many years, only one manufacturer produced the AGID 
kit for EBL testing in Brazil, even though it was produced in an insufficient amount to supply the full demand for tests in the country, since the antigen used was dependent on viral cultures in cell lines, a time consuming and complex production process when performed at a large scale, as required for the AGID. Aditionally the production of this kit has been



Fig.4. Comparison of the results of 72 samples tested by indirect enzyme-linked immunosorbent assay (iELISA) and the Chekit ELISA. Negative samples by Chekit ELISA (0), positive samples by Chekit ELISA (1).

Table 1. Comparative analysis between the iELISA and AGID tests on 73 bovine samples

\begin{tabular}{lccc}
\hline \multirow{2}{*}{ AGID } & \multicolumn{3}{c}{ iELISA } \\
\cline { 2 - 4 } & Positive & Negative & Total \\
\hline Positive & 34 & 2 & 36 \\
Negative & 9 & 28 & 37 \\
Total & 43 & 30 & 73 \\
& & \\
Sens.\% & 94.44 \\
Spec.\% & 75.68 \\
PPV\% & 79.1 \\
NPV\% & 93.3 \\
Agree.\% & 84 \\
Kappa & 0.699 \\
\hline iELISA = indirect enzyme-linked immunosorbent assay, Sens. = sensitivity, \\
Spe. = specificity, PPV= positive predictive value, NPV = negative predictive \\
value, Agree. = agreement, Kappa = Fleiss' Kappa index, AGID = agar gel \\
immunodiffusion.
\end{tabular}

discontinued. According to our estimate for the AGID test, $25 \mu \mathrm{L}$ of pure antigen is required for three samples each, while in the iELISA, the same amount of antigen was sufficient for 96 samples simultaneously. There are no national commercial ELISA kits available in Brazil and the importation of these kits is an expensive and often time-consuming process, making it an unfeasible method to be used at a large scale. Furthermore, many of these assays utilize antigen preparations from cultures of persistently BLV-infected FLK cells, which are susceptible to BVDV contamination. In studies by Oliveira et al. (2013), 88 samples belonging to 32 cell cultures of different species, obtained from eight laboratories, were tested for different contaminants. Of the 88 samples, 21 (23.9\%) were positive for BVDV by PCR, including three FLK samples from the three different batches analyzed. To minimize nonspecific reactions and to increase the specificity of the test, a BVDV-free Tb1 Lu cell line was infected with BLV and was used to produce antigen for the standardization of the iELISA, which proved to be an efficient alternative for this purpose.

Viral protein gp51 is the main partially-purified protein in the antigen preparation used in this work, as determined by SDS-PAGE (Fig.1). BLV-infected animals develop a humoral response characterized by the production of high titers of antibodies, especially against the $\mathrm{p} 24$ and gp 51 proteins. This justifies the widespread use of these antigens in serological diagnostic tests, mainly gp51, considering that antibodies against it reach higher titers and are detected earlier than those produced against p24 (Gutiérrez et al, 2009).

BLV appears to exhibit less genetic variability when compared to other retroviruses; however, phylogenetic studies of the env gene of strains isolated from several countries have

Table 2. Comparative analysis between the iELISA and Chekit ELISA tests on 72 bovine samples

\begin{tabular}{lccc}
\hline \multirow{2}{*}{ Chekit ELISA } & \multicolumn{3}{c}{ iELISA } \\
\cline { 2 - 4 } & Positive & Negative & Total \\
\hline Positive & 38 & 3 & 41 \\
Negative & 4 & 27 & 31 \\
Total & 42 & 30 & 72 \\
& & & \\
Sens.\% & & 92.6 & \\
Spec.\% & & 87.09 & \\
PPV\% & 90.47 & \\
NPV\% & & 90.0 & \\
Agree.\% & & 90.27 & \\
Kappa & & 0.801 & \\
\hline
\end{tabular}

iELISA = indirect enzyme-linked immunosorbent assay, Sens. = sensitivity, Spec. $=$ specificity, $\mathrm{PPV}=$ positive predictive value, $\mathrm{NPV}=$ negative predictive value, Agree $=$ agreement, Kappa $=$ Fleiss' Kappa index .

Table 3. Relation of the results obtained in the AGID, iELISA and commercial Chekit ELISA tests of serum samples from CF and NCF calves

\begin{tabular}{|c|c|c|c|c|c|c|}
\hline \multirow{2}{*}{ Sera } & \multicolumn{2}{|c|}{ AGID } & \multicolumn{2}{|c|}{ iELISA } & \multicolumn{2}{|c|}{ ELISA Chekit } \\
\hline & Positive & Negative & Positive & Negative & Positive & Negative \\
\hline $\mathrm{CF}$ & $34(46.6 \%)$ & $7(9.6 \%)$ & $40(54.8 \%)$ & $1(1.4 \%)$ & $37(51.4 \%)$ & $3(4.2 \%)$ \\
\hline $\mathrm{NCF}$ & $2(2.7 \%)$ & 30 (41.1\%) & $3(4.1 \%)$ & 29 (39.7\%) & $3(4.2 \%)$ & $29(40.2 \%)$ \\
\hline Total & \multicolumn{2}{|c|}{73} & \multicolumn{2}{|c|}{73} & \multicolumn{2}{|c|}{72} \\
\hline
\end{tabular}

AGID = agar gel immunodiffusion, iELISA = indirect enzyme-linked immunosorbent assay, $\mathrm{CF}=$ colostrum-fed, NCF = non-colostrum-fed. 
shown that this virus is classified into, at least, ten distinct genotypes according to variations in gp51. These variations are preferentially located in the conformational epitopes $\mathrm{F}, \mathrm{G}$ and $\mathrm{H}$ of the gp51 protein (Camargos et al. 2004, Gautam et al. 2018). These epitopes induced the production of neutralizing antibodies and it was speculated that they may influence the antigenic characteristics of the virus and reduce the sensitivity of the diagnostic methods, especially serological methods. The use of antigen from a BLV Brazilian isolate for indirect ELISA may be an advantage, as the variability among strains is associated with different geographic regions. In addition, glycosylation sites, important for cell recognition processes, such as virus binding to cell receptors and cell-cell fusion, are highly conserved among the different BLV strains, maintaining the essential functions of the protein (Camargos et al. 2004, Polat et al. 2016). However, to better assess this interference, it would be necessary to test a larger number of samples from different geographic origins.

The iELISA developed in this study had high sensitivity (94.44\%) and considerable specificity (75.68\%), identifying nine positive results more than AGID. This could be explained by the increased sensitivity related to the use of a BLV Brazilian strain or by a low titer of antibodies in the serum of these animals that was undetectable by the AGID. Additionally, it could have even been a reading error, as the reading of these test results are subjective and susceptible to misinterpretation, which may compromise the diagnostic accuracy and consequently, impair the efficiency of control programs. Furthermore, four $(5.47 \%)$ samples with a weak positive result in AGID showed a high OD reading in the iELISA, and thus were classified as positive. The ability of our iELISA to detect positive animals is one of the main advantages of the test and is in agreement with other ELISAs previously described in the literature (Troiano et al. 2013, Larsen et al. 2017). Weak reactions to AGID that are positive in the iELISA are an important intrinsic feature of the test, since this type of reaction is more difficult to detect and can easily go unnoticed due to reader errors in the AGID.

Unexpectedly, two samples collected from NCF animals were positive by AGID and negative in the iELISA. These results were considered as false positives in AGID. It was also hypothesized that these calves were born from infected cows and BLV was transmitted during pregnancy or childbirth. Animals fed colostrum and negative by AGID, were positive in at least one of the ELISAs, which likely indicated a false negative result of the AGID test in these cases.

Compared to the Chekit Leucose Serum ELISA, the iELISA showed a higher sensitivity and classified one sample as positive that was undetermined by the commercial test. This demonstrated that the developed assay had a similar performance to the commercial assay and could be used as an alternative to the Chekit Leucose-Serum ELISA, with the advantage of being more economically feasible and accessible to producers and laboratories.

EBL control is difficult due to its wide distribution, slow evolution, and the presence of a large number of asymptomatic animals that go unnoticed by breeders. In addition, the lack of knowledge among producers and technicians on the real importance of the disease as a source of damage contributes to the spread of the virus. In the United States, where the low risk of tumor development is not seen as a reason to control the spread of the virus, there are no efforts to do appropriate controls; thus, the annual economic loss associated with this infection is estimated at 500 million dollars (Ott et al. 2003, Rajão et al. 2014). The identification of positive animals is necessary to control virus propagation; in this perspective, the developed iELISA allows a better understanding of the true serological status of the herds in Brazil and studies of the impact of the disease on productivity, contributing to a better control of EBL.

Another important issue regarding BLV infection and its widespread distribution is its zoonotic potential as a causative agent of breast cancer in humans. Buehring et al. (2003) identified for the first time the presence of antibodies against the viral capsid protein p24 in human serum samples. After this finding, several studies have shown the presence of proviral DNA in the blood (Buehring et al. 2019) and breast tissue of women diagnosed with cancer in the USA, Australia, Iran and Brazil (Buehring et al. 2014, 2017, Khalilian et al. 2019, Schwingel et al. 2019). How virus transmission occurs remains unclear, but it is speculated that it is by ingestion of bovine products, such as milk and meat infected with BLV (Buehring et al. 2015, Cuesta et al. 2018). The genome of BLV has been detected in unpasteurized milk and raw meat, supporting this hypothesis (Olaya-Galán et al. 2017). Considering this information and the high prevalence of BLV in herds, especially dairy cattle, the use of an efficient diagnostic test to detect positive animals is fundamental, not only because of the economic importance of the disease, but also because it represents a possible problem of food safety and public health.

\section{CONCLUSION}

The indirect ELISA standardized using gp51 antigen produced in Tadarida brasiliensis lung (Tb1Lu) cells infected with a bovine leukemia virus Brazilian isolate presented high sensitivity for the diagnosis of enzootic bovine leukosis (EBL) and could be used as a screening test in serological surveys. To increase the accuracy of EBL diagnosis, we suggest that the iELISA should be used as a screening test, and positive cases should be confirmed in a complementary test, such as AGID, based on its high specificity.

Acknowledgements.- This work was supported by the "Conselho Nacional de Desenvolvimento Científico e Tecnológico" (CNPq, grant no. 481772.2013-8), "Coordenação de Aperfeiçoamento de Pessoal de Nível Superior" (CAPES), "Fundação de Amparo à Pesquisa de Minas Gerais" (FAPEMIG) and "Instituto Nacional de Ciência e Tecnologia" (INCT - Pecuária).

Conflict of interest statement.- The authors declare that they have no competing interests.

\section{REFERENCES}

Bai L., Yokoyama K., Watanuki S., Ishizaki H., Takeshima S.N. \& Aida Y. 2019. Development of a new recombinant p24 ELISA system for diagnosis of bovine leukemia virus in serum and milk. Arch Virol. 164(1):201-211. <https://dx.doi.org/10.1007/s00705-018-4058-5> <PMid:30311076>

Beier D. \& Conraths F.J. 1996. Abkl"arung fraglicher und falsch-positiver Ergebnisse in einem Testbesteck zum Nachweis von Antik"orpern gegen das bovine Leukosevirus (BLV) und m "ogliche Zusammenh"ange zu BVD/MDImpfungen. Mitteilungsblatt zur Tierseuchensituation der Bundesrepublik Deutschland, BFAV, I. Halbjahr. (apud Beier D., Riebe R., Blankenstein P., Starick E., Bondzio A. \& Marquadt O. 2004. Establishment of a new bovine leukosis virus producing cell line. J. Virol. Methods 121(2):239-246. <https://dx.doi.org/10.1016/j.jviromet.2004.06.017><PMid:15381362>) 
Buehring G.C., DeLaney A., Shen H., Chu D.L., Razavian N., Schwartz D.A., Demkovich Z.R. \& Bates M.N. 2019. Bovine leukemia virus discovered in human blood. BMC Infect Dis. 19(1):297. <https://dx.doi.org/10.1186/ s12879-019-3891-9><PMid:30940091>

Buehring G.C., Philpott S.M. \& Choi K.Y. 2003. Humans have antibodies reactive with bovine leukemia virus. AIDS Res. Hum. Retroviruses 19(12):1105-1113. <https://dx.doi.org/10.1089/088922203771881202><PMid:14709247>

Buehring G.C., Shen H., Schwartz D.A. \& Lawson J.S. 2017. Bovine leukemia virus linked to breast cancer in Australian women and identified before breast cancer development. Plos One 12(6)e0179367. <https://dx.doi. org/10.1371/journal.pone.0179367><PMid:28640828>

Buehring G.C., Shen H.M., Jensen H.M., Choi K.Y., Sun D. \& Nuovo G. 2014. Bovine leukemia virus DNA in human breast tissue. Emerg. Infect. Dis. 20(5):772782. <https://dx.doi.org/10.3201/eid2005.131298><PMid:24750974>

Buehring G.C., Shen H.M., Jensen H.M., Jin D.L., Hudes M. \& Block G. 2015. Exposure to bovine leukemia virus is associated with breast cancer: a casecontrol study. PLoS One 10(9)e0134304. <https://dx.doi.org/10.1371/ journal.pone.0134304><PMid:26332838>

Camargos M.F., Feliziani F., De Giuseppe A. \& Lessa L.M. 2007. Evaluation of diagnostic tests to bovine leukemia vírus. Revta Port. Ciênc. Vet. 102(561562):169-173.

Camargos M.F., Melo C.B., Leite R.C. \& Stancek D. 2002. Frequência de soropositividade para a leucose enzoótica bovina em rebanhos de Minas Gerais. Ciênc. Vet. Trop. 5:20-26.

Camargos M.F., Reis J.K.P. \& Leite R.C. 2004. Bovine leukemia virus. Virus Rev. Res. 9(1):44-59.

Carneiro P.A.M., Araujo W.P., Birgel E.H. \& Souza K.W. 2003. Prevalência da infecção pelo Vírus da Leucose dos Bovinos em rebanhos leiteiros criados no estado do Amazonas, Brasil. Acta Amaz. 33(1):111-125. <https://dx.doi. org/10.1590/1809-4392200331125>

Cuesta L.M., Lendez P.A., Farias M.V.N., Dolcini G.L. \& Ceriani M.C. 2018. Can bovine leukemia virus be related to human breast cancer? A review of the evidence. J. Mammary Gland Biol. Neoplasia 23(3):101-107. <https:// dx.doi.org/10.1007/s10911-018-9397-z><PMid:29777406>

De Oliveira C.H.S., Resende C.F., Oliveira C.M., Barbosa J.D., Fonseca Junior A.A., Leite R.C. \& Reis J.K.P. 2016. Absence of bovine leukemia virus (BLV) infection in buffaloes from Amazon and southeast region in Brazil. Prev. Vet. Med. 129:9-12. <https://dx.doi.org/10.1016/j.prevetmed.2016.05.002> <PMid:27317318>

Gautam S., Mishra N., Kalaiyarasu S., Jhade S.K. \& Sood R. 2018. Molecular characterization of Bovine leukaemia virus (BLV) strains reveals existence of genotype 6 in cattle in India with evidence of a new subgenotype. Transbound. Emerg. Dis. 65(6):1968-1978. <https://dx.doi.org/10.1111/ tbed.12979> <PMid:30044055>

Graves D.C. \& Ferrer J.F. 1976. In vitro transmission and propagation of the bovine leukemia virus in monolayer cell cultures. Cancer Res. 36(11 Pt):4152-4159. <PMid:61801>

Gutiérrez G., Alvarez I., Fondevila N., Politzki R., Lomónaco M., Rodríguez S., Dus Santos M.J. \& Trono K. 2009. Detection of Bovine leukemia virus specific antibodies using recombinant p24-ELISA. Vet. Microbiol. 137(3/4):224-234. <https://dx.doi.org/10.1016/j.vetmic.2009.01.022><PMid:19201553>

Khalilian M., Hosseini S.M. \& Madadgar O. 2019. Bovine leukemia virus detected in the breast tissue and blood of Iranian women. Microb. Pathog. 135:103566. <https://dx.doi.org/10.1016/j.micpath.2019.103566> $<$ PMid:31252065>

Lage D.P., Martins V.T., Duarte M.C., Costa L.E., Garde E., Dimer L.M., Kursancew A.C.S., Chávez-Fumagalli M.A., Magalhães-Soares D.F., Menezes-Souza D., Roatt B.M., Machado-de-Ávila R.A., Soto M., Tavares C.A.P. \& Coelho E.A.F. 2016. A new Leishmania-specific hypothetical protein and its non-described specific B cell conformational epitope applied in the serodiagnosis of canine visceral leishmaniasis. Parasitol. Res. 115(4):1649-1658. <10.1007/ s00436-016-4904-x><PMid:26782811>
Larsen A., Corva S., Panei J., Geisler C. \& Mortola E. 2017. Enzyme-linked immunosorbent assays using the recombinant gp51 and p24 of Bovine leukemia virus for immunodetection of the disease. OJAS 7(3):241-253. <https://dx.doi.org/10.4236/ojas.2017.73019>

Larsen A., Gonzalez E.T., Serena M.S., Echeverría M.G. \& Mortola E. 2013. Expression of p24 gag protein of Bovine leukemia virus in insect cells and its use in immunodetection of the disease. Mol. Biotechnol. 54(2):475-483. <https://dx.doi.org/10.1007/s12033-012-9587-7> <PMid:22829115>

Leite R.C., Reis J.K.P., Oliveira A.P., Nascimento P.M.P., Oliveira F.G., Naves J.H.F.F., Rodrigues A.P.S., Gasparini M.S., Alves F., De Oliveira C.H.S., Rajão D.S. \& Galinari G.C.F. 2013. Retroviroses dos animais domésticos. Vet. Zootec. 20:73-92.

Megid J., Nozaki C.N., Kuroda R.B.S., Cruz T.F. \& Lima K.C. 2003. Ocorrência de leucose enzoótica bovina na microrregião da Serra de Botucatu. Arq. Bras. Med. Vet. Zootec. 55(5):645-646. <https://dx.doi.org/10.1590/ S0102-09352003000500021>

Molnár É., Molnár L., Dias H.T., Silva A.O.A. \& Vale W.G. 1999. Ocorrência da leucose enzoótica dos bovinos no estado do Pará, Brasil. Pesq. Vet. Bras. 19(1):7-11. <https://dx.doi.org/10.1590/S0100-736X1999000100002>

Nekouei O., VanLeeuwen J., Stryhn H., Kelton D. \& Keefe G. 2016. Lifetime effects of infection with Bovine leukemia virus on longevity and milk production of dairy cows. Prev. Vet. Med. 133:1-9. <https://dx.doi.org/10.1016/j. prevetmed.2016.09.011><PMid:27720022>

OIE 2012. Enzootic bovine leucosis, p.721-731. In: Ibid. (Eds), Manual of Diagnostic Tests and Vaccines for Terrestrial Animals (mammals, birds and bees). Vol.1. 7th ed. World Organisation for Animal Health, Paris.

Olaya-Galán N.N., Corredor-Figueroa A.P., Guzmán-Garzón T.C., Ríos-Hernandez K.S., Salas-Cárdenas S.P., Patarroyo M.A. \& Gutierrez M.F. 2017. Bovine leukaemia virus DNA in fresh milk and raw beef for human consumption. Epidemiol. Infect. 145(15):3125-3130. <https://dx.doi.org/10.1017/ S0950268817002229><PMid:28956522>

Oliveira T. F.P., Fonseca Junior A.A., Camargos M.F., de Oliveira A.M., Cottorello A.C.P., Ados R.S., Almeida I.G. \& Heinemann M.B. 2013. Detection of contaminants in cell culture, sera and trypsin. Biologicals 41(6):407-414. <https://dx.doi.org/10.1016/j.biologicals.2013.08.005><PMid:24071554>

Ott S.L., Johnson R. \& Wells S.J. 2003. Association between bovine leukosis soroprevalence and herd level productivity on US dairy farms. Prev. Vet. Med. 61(4):249-262. <https://dx.doi.org/10.1016/j.prevetmed.2003.08.003> $<$ PMid:14623410>

Patrascu I.V. 1988. Bovine leukemia virus. VII. In vitro replication of virus in bat lung cell culture NBL BLV 2. Virologie 39(3):199-205. <PMid:2848358>

Polat M., Takeshima S.N., Hosomichi K., Kim J., Miyasaka T., Yamada K., Arainga M., Murakami T., Matsumoto Y., de la Barra Diaz V., Panei C.J., González E.T., Kanemaki M., Onuma M., Giovambattista G. \& Aida Y. 2016. A new genotype of bovine leukemia virus in South America identified by NGS-based whole genome sequencing and molecular evolutionary genetic analysis. Retrovirology 13:4. <https://dx.doi.org/10.1186/s12977-016-0239-z> <PMid:26754835>

Poletto R., Kreutz L.C., Gonzales J.C. \& Barcellos L.J.G. 2004. Prevalência de tuberculose, brucelose e infecções víricas em bovinos leiteiros do município de Passo Fundo, RS. Ciênc. Rural 34(2):595-598. <https:// dx.doi.org/10.1590/S0103-84782004000200043>

Rajão D.S., Heinemann M.B., Reis J.K.P., Braz G.F., Haddad J.P.A., Ribeiro A.C.C.L. \& Leite R.C. 2014. Effects of bovine leukemia virus infection on crossbred and purebred dairy cattle productive performance in Brazil. Semina, Ciênc. Agrárias 35(2):891-900. <https://dx.doi.org/10.5433/16790359.2014v35n2p891>

Romero C.H. \& Rowe C.A. 1981. Enzootic bovine leukosis virus in Brazil. Trop. Anim. Health Prod. 13(2):107-111. <https://dx.doi.org/10.1007/ BF02237902> <PMid:6262958>

Schwingel D., Andreolla A.P., Erpen L.M.S., Frandoloso R. \& Kreutz L.C. 2019. Bovine leukemia virus DNA associated with breast cancer in women from South Brazil. Nature 9:2949.<https://dx.doi.org/10.1038/s41598-019-39834-7> 
SuzukiT.,Ikeda H. \& Mase M.2018. Restricted viral cDNA synthesis in cell lines that fail to support productive infection by bovine leukemia virus. Arch Virol.163(9):24152422. <https://dx.doi.org/10.1007/s00705-018-3887-6><PMid:29796925>

Trainin Z \& Brenner J. 2005. The direct and indirect economics impacts of bovine leukemia virus infection on dairy cattle. Israel J. Vet. Med. 60:94-105.
Troiano L.D.C., Thomaz-Soccol V., Agottani J.V.B., Brodzinski J., Penha T.R. \& Ozaki S.C. 2013. Production, characterization, and use of monoclonal antibodies against gp51 protein to diagnose bovine leukemia virus infection. Biores Open Access 2(1):55-60. <https://dx.doi.org/10.1089/ biores.2012.0295> <PMid:23515423> 